\title{
PENGARUH ANALISIS PROSPEKTUS DAN MANAJEMEN LABA TERHADAP INITIAL RETURN DI BURSA EFEK INDONESIA
}

\author{
Yona Octiani Lestari \\ Jurusan Manajemen Fakultas Ekonomi UIN Maulana Malik Ibrahim Malang \\ Jln. Gajayana 50 Malang, Telepon (0341) 558881,Fax.(0341) 558881, \\ E-mail: yonaoctiani@yahoo.com
}

\begin{abstract}
Research target is test prospectus information influence to initial return. Sample Research as much 53 manufacturing and non manufacturing doing tender in JSX (Jakarta Stock Exchange) at range of time 2005-2007. Intake sample method by purposive sampling with equity criterion which underpricing prospectus report and published fulfill data equipment. Analyse data use doubled regression to test strength of among auditor reputation, emission guarantor reputation, old age company, equity percentage which on the market, ROA, leverage, industrial sector of earning management with initial return. Result of analysis indicate that there is two variable having an effect on significance to initial return that is emission guarantor reputation and auditor reputation. Assess significance T for the auditor reputation is 0.037 meaning significance at $5 \%$. While result of test correlation indicate that emission guarantor reputation variable can explain initial return equal to 0.200 or equal to $20 \%$ positive to initial return. This result support research which have been done by Balvers ( 1998) that is emission guarantor reputation and auditor reputation have an effect on negativity significance to initial return.
\end{abstract}

Kata Kunci: IPO, manajemen laba, intial return, analisis prospektus.

Pada saat perusahaan go public di Indonesia (untuk pertama kali menjual sahamnya) terdapat kecenderungan terjadinya underpricing. Di beberapa negara berkembang di Amerika Latin gejala adanya underpricing dalam jangka pendek juga terjadi tetapi dalam jangka panjang kondisi akan berbalik yaitu terjadi overpricing (Aggarwal et.al.,1993). Proses penawaran saham perdana atau initial public offering (IPO) masih rentan dengan adanya manajemen laba yang memicu timbulnya asimetri informasi antara investor dan emiten saat melakukan IPO. Seperti yang diungkapkan oleh Rao (1993) bahwa ketika terjadi IPO investor memiliki keterbatasan untuk menggunakan media informasi yang mencakup informasi perusahaan pada saat tahun sebelum IPO. Informasi yang dapat diandalkan terbatas pada informasi prospektus yang hanya memuat informasi satu sampai tiga tahun laporan keuangan. 
Healy (1985) menyatakan manajemen laba yang dilakukan oleh manajemen dapat menggunakan dua cara yaitu dengan memilih prosedur akuntansi atau mengontrol berbagai akrual, apabila manajemen menggunakan pemilihan metode akuntasi, maka akan mudah diketahui pembaca laporan keuangan, sedangkan bila mengontrol akrual yang terjadi pada perusahaan akan sulit terdeteksi. Healy (1985) menemukan bukti bahwa penggunaan angka akuntansi kontrak bonus akan memicu manajer untuk menyesuaikan tingkat laba agar dapat memaksimumkan bonus yang mereka nikmati.

IPO berfokus pada initial return yang didefinisikan sebagai return positif yang diterima investor di pasar perdana yang diperoleh dari selisih antara harga surat berharga pada saat penawaran umum (offering price) dengan harga jual saat di pasar sekunder (Balvers et al. 1988). Masalah initial return ini menarik beberapa peneliti karena fenomena sebagian besar pasar dunia mengalami underpricing. Di Indonesia pengamatan perilaku harga saham di pasar perdana selama tahun 1990 menunjukkan fenomena underpricing (Husnan,1991). Fenomena underpricing menunjukkan adanya return positif yang diterima investor pada pasar perdana. (Balvers et.al.,1988; Beatty,1989; Carter Manaster,1990).

Cristy et.al (1996) mengemukakan bahwa prosentase penawaran saham saat IPO berpengaruh negatif signifikan terhadap initial return dan untuk variabel umur perusahaan berpengaruh positif signifikan terhadap initial return. Hal ini mendukung hipotesis ketiga dan keempat bahwa diduga ada pengaruh antara prosentase penawaran saham dan umur perusahaan terhadap initial return.

Menurut yang dikemukakan oleh Kim et.al (1993) bahwa reputasi penjamin emisi berpengaruh positif dengan initial return. Pada penelitian ini juga menguji variabel keuangan yaitu ROA dan financial leverage. Hasil penelitiannya menunjukkan variabel financial leverage berkolerasi positif dengan initial return, sedangkan variabel ROA berkorelasi negatif dengan initial return.

Financial leverage juga dipertimbangkan sebagai variabel keuangan dalam penelitian ini karena secara teoritis financial leverage menunjukkan risiko suatu perusahaan sehingga berdampak pada ketidakpastian suatu harga saham (Kim et.al,1993). Financial leverage menunjukkan kemampuan perusahaan dalam membayar hutangnya dengan equity yang dimiliki, apabila financial leverage tinggi menunjukkan risiko suatu perusahaan dan investor dalam menanamkan modalnya akan mempertimbangkan hal ini. 
Merujuk dari penelitian yang dilakukan oleh Trisnawati (1998) bahwa financial leverage dan ukuran perusahaan yang berpengaruh signifikan terhadap initial return. Daljono (2000) bahwa reputasi penjamin emisi yang berpengaruh terhadap initial return dan peneliti lain sebelumnya, maka penelitian saat ini masih menguji informasi prospektus dan memasukkan manajemen laba. Unsur manajemen laba dirasa ada hubungan signifikan dengan initial return. Scott (1997) bahwa seorang manajer akan memilih satu metoda atau kebijakan akuntansi tertentu yang diperbolehkan oleh GAAP dengan harapan dapat memaksimumkan utility mereka atau meningkatkan nilai perusahaan. Cara yang digunakan oleh manajer untuk mempengaruhi angka laba secara sistematis dan sengaja dengan cara memilih kebijakan akuntansi dan prosedur akuntansi tertentu bertujuan memaksimumkan utility manajer dan harga saham yang disebut manajemen laba (Earning Management). Rentang tahun untuk sampel adalah tahun selama krisis moneter dengan menambah variabel independen, yaitu adanya praktik manajemen laba

Sehingga jumlah variabel independen yang diuji pada penelian ini sebanyak 8 buah antara lain reputasi auditor, reputasi penjamin emisi, umur perusahaan, prosentase saham yang ditawarkan, return on asset, financial leverage, sektor industri dan manajemen laba. Maka dengan pengembangan model penelitian kali ini akan diuji besarnya pengaruh variabel indenpenden terhadap initial return sebagai variabel dependennya.

\section{Asimetri Informasi}

Terjadinya asimetri informasi karena ketidakseimbangan informasi yang dimiliki oleh satu pihak dengan pihak lain. Jensen dan Meckling (1976) menyimpulkan bahwa hubungan keagenan sebagai suatu kontrak dilakukan oleh satu atau beberapa orang (prinsipal) yang menggunakan orang lain (agen) untuk melakukan beberapa jasa untuk kepentingan prinsipal dengan cara mendelegasikan beberapa otoritas pengambilan keputusan kepada agen, Agency Theory mengimplikasikan adanya asimetri informasi antara manajer sebagai agen dan pemegang saham sebagai prinsipal.

Menurut Scott (1997) timbulnya asimetri informasi karena satu pihak memiliki pengetahuan yang tidak dimiliki oleh pihak lain. Terdapat dua jenis asimetri informasi yaitu adverse selections dan moral hazard. Adverse selections berkaitan erat dengan pihak dalam (manajemen) kepada pihak luar (investor). 


\section{Penawaran Saham Perdana (IPO)}

Banyak perusahaan yang berupaya untuk melakukan ekspansi. Salah satu alternatif pemenuhan dana adalah dengan melakukan go public. Husnan (1996) menyatakan bahwa dengan menerbitkan saham di pasar modal berarti perusahaan tidak hanya dimiliki oleh pemilik lama tapi juga dimiliki oleh masyarakat, hal ini memungkin kan pemilik lama memiliki fair prices atas saham yang ditawarkan perusahaan. Fair prices terjadi karena proses penawaran saham di pasar modal melibatkan banyak pelaku pasar modal yang informasi lebih transparan.

Hasil penelitian Beatty (1989) menunjukkan bahwa reputasi auditor berhubungan secara statistik signifikan dan negatif dengan initial return. Sedangkan reputasi penjamin emisi, prosentase penawaran saham, tipe kontrak penjamin emisi,dan umur perusahaan berasosiasi secara statistik signifikan dan positif dengan initial return. Dalam peneliannya menggunakan variabel kontrol (control variable), sample yang digunakan adalah 2215 perusahaan yang melakukan IPO selama kurun waktu 1975-1984, rata-rata initial return menunjukkan 22,1 \% pada perioda tersebut, alat analisis yang digunakan adalah Multiple Regression.

Balvers et.al (1988) dengan menggunakan sample sebanyak 1182 perusahaan yang melakukan IPO sepanjang tahun 1981-1985 di NYSE (New York Stock Exchange) mengemukakan bahwa auditor yang bereputasi dan penjamin emisi yang bereputasi berpengaruh negatif terhadap initial return. Keduanya mengurangi tingkat underpricing.

\section{Underpricing Saham Perdana}

Pada model Rock (1986) informasi asimetri terdapat dalam kelompok informed investor dan uninformed investor. Informed investor mengetahui informasi lebih banyak menganai prospek perusahaan emiten akan membeli saham-saham IPO jika after market price yang diharapkan melebihi harga perdana atau dengan kata lain kelompok ini hanya membeli sahamsaham IPO yang underpricing saja, sementara kelompok uninformed karena kurang memiliki informasi mengenai perusahaan emiten malakukan penawaran secara sembarangan baik pada saham-saham IPO yang underpricing maupun yang overpricing. 


\section{Informasi Prospektus}

\section{Reputasi Auditor}

Bavers et.al (1998) melakukan penelitian dengan judul: Underpricing of new issues and the choice of auditor as a signal invesment banker reputations, tentang pengaruh reputasi auditor, reputasi penjamin emisi terhadap initial return. Hasil analisisnya adalah bahwa reputasi auditor dan reputasi penjamin emisi berpengaruh negatif signifikan terhadap initial return.

Beatty (1989) melakukan penelitian dengan judul: Auditor reputations and the pricing of initial public offering, untuk menguji pengaruh beberapa variabel yaitu reputasi auditor, reputasi penjamin emisi, prosentase penawaran saham, umur perusahaan, tipe penjamin emisi dan indikator perusahaan terhadap initial return. Hasil penelitian menunjukkan bahwa initial return dipengaruhi oleh reputasi auditor, reputasi underwriter, prosentase penawaran saham, umur perusahaan, tipe penjamin emisi dan inidikator perusahaan.

H1: Terdapat hubungan negatif yang signifikan antara reputasi auditor dengan initial return

\section{Reputasi Underwriter}

Balvers et.al (1988) melakukan penelitian dengan judul : Underpricing of new issues and the choice of auditor as a signal invesment banker reputations. Penelitian tersebut tentang pengaruh reputasi auditor dan reputasi underwriter terhadap initial return. Dengan menggunakan perioda pengamatan selama tahun 1981 sampai dengan tahun 1985, diperoleh sampel sebanyak 1182 perusahaan yang melakukan IPO. Hasil analisisnya menunjukkan bahwa reputasi auditor dan reputasi underwriter berpengaruh negatif terhadap initial return.

Carter dan Manaster (1990) yang melakukan penelitian dengan judul : Initial Public Offering and Underwriter Reputation, mengemukakan bahwa reputasi underwriter berkaitan dengan risiko IPO. Dengan menggunakan perioda pengamatan selama bulan januari 1979 sampai dengan bulan agustus tahun 1985 dan sampel sebanyak 501 perusahaan yang melakukan IPO, hasilnya menunjukkan bahwa saham yang Lower Risk Offering dijamin oleh underwriter yang bereputasi. Dengan demikian dapat dikembangkan hipotesis yang kedua yaitu

H2: Terdapat hubungan negatif yang signifikan antara reputasi underwriter dengan initial return 


\section{Umur Perusahaan}

McGuinnes (1992) bahwa suatu penjelasan mengenai fenomena underpricing adalah adanya hipotesis asimetri informasi. Asimetri informasi terjadi antara perusahaan emiten dan perusahaan penjamin (model Baron) atau antara investor informed dan investor uninformed (model Rock).

Dalam model Baron, penjamin dianggap memiliki informasi yang lebih baik mengenai permintaan saham-saham perusahaan emiten daripada perusahaan emiten sendiri. Model ini mengimplikasikan bahwa ketidakpastian yang besar dari suatu perusahaan emiten tentang harga saham maka permintaan terhadap jasa penjamin saham akan semakin besar. Kompensasi atas informasi yang diberikan penjamin antara lain dengan mengijinkan penjamin menawarkan saham pada harga dibawah harga ekuilibrium. Oleh karena itu lebih tinggi ketidakpastiannya, lebih banyak masalah dalam menentukan harga dan lebih tinggi underpricing (McGuinnes, 1992)

\section{H3: Terdapat hubungan negatif yang signifikan antara umur perusahaan dengan initial return}

\section{Prosentase Penawaran Saham}

Carter dan Dark (1992) melakukan penelitian dengan judul : An empirical examination of invesment banking reputations measures, menemukan pengaruh yang negatif antara IPO return dengan reputasi underwriter, prosentase penawaran saham, umur perusahaan, gross proceed dan standar deviasi return.

Cristy et.al (1996) dengan judul: A note on underwriter competitions and intial public offering. Penelitian tersebut menggunakan perioda waktu selama 5 tahun mulai tahun 1979 sampai dengan tahun 1984 dan sampel yang digunakan 599 perusahaan untuk menguji initial return saham setelah 15 hari dari tanggal IPO. Hasil analisis menunjukkan variabel-variabel yang diuji tidak berpengaruh signifikan dengan IPO return. Oleh karena itu diajukan hipotesis sebagai berikut :

H4: Terdapat hubungan positif yang signifikan antara prosentase saham yang ditawarkan kepada publik dengan initial return 


\section{Profitabilitas Perusahaan}

Bringham dan Gapenski (1997) oleh Usman (2000) mengemukakan bahwa rasio profitabilitas pada dasarnya mengukur seberapa besar kemampuan perusahaan dalam memanfaatkan sumberdayanya dalam suatu perioda tertentu secara efektif. Rasio ini dirancang untuk mengetahui apakah jumlah tiap jenis aktiva yang dimiliki perusahaan tersebut masuk akal, terlalu tinggi atau rendah dilihat dari sudut pandang penjualan sekarang maupun yang akan datang.

Sedangkan financial leverage berpengaruh statistik signifikan dan positif dengan initial return. Pada penelian Kim et.al (1993) ini menguji penyebab underpricing di pasar Korea dan hasilnya menunjukkan bahwa variabel keuangan yaitu profitabilitas keuangan yang diukur ROA dan financial leverage, profitabilitas perusahaan memberikan informasi kepada pihak luar mengenai efektifitas operasional perusahaan.

\section{H5: Terdapat hubungan negatif yang signifikan antara profitabilitas perusahaan (ROA) dengan initial return.}

\section{Financial Leverage}

Bringham dan Gapenski (1997) yang dikutip oleh Usman (2000) menyatakan bahwa perluasan perusahaan dengan menggunakan hutang atau financial leverage mempunyai tiga implikasi yaitu (1) dengan meningkatkan hutang, pemodal tidak berkurang kekuatannya dalam mengendalikan perusahaan, (2) dengan adanya pinjaman, sebagian risiko akan ditanggungan oleh kreditur, (3) bila profit lebih besar dari biaya hutang return bagi pemodal akan meningkat. Sebaliknya bila profit lebih kecil dari biaya bunga maka return pemodal akan turun.

Dalam kondisi normal perusahaan dengan tingkat rasio hutang yang tinggi memliki expected return yang tinggi pula. Tetapi perusahaan yang menggunakan leverage tinggi akan memiliki tingkat yang tinggi pula (Bringham dan Gapenski, 1997).

\section{H6: Terdapat hubungan positif yang signifikan antara financial leverage dengan intial return}

\section{Sektor Industri}

Pada umumnya perusahaan manufaktur lebih dikenal oleh masyarakat dibandingkan perusahaan non manufaktur sehingga informasi yang dihasilkan juga lebih banyak (Cooke,1998). Dengan informasi tersebut maka dapat digunakan oleh investor untuk 
membantu dalam mengambil suatu keputusan investasi. Berdasarkan hal tersebut perlu diajukan sebuah hipotesis sebagai berikut:

\section{H7: Terdapat hubungan negatif yang signifikan antara sektor industri dengan initial return}

\section{Manajemen Laba}

Seperti yang diungkapkan Scott (1997) bahwa seorang manajer akan memilih satu metoda atau kebijakan akuntansi tertentu yang diperbolehkan oleh GAAP dengan harapan dapat memaksimumkan utility mereka atau meningkatkan nilai perusahaan. Cara yang digunakan oleh manajer untuk mempengaruhi angka laba secara sistematis dan sengaja dengan cara memilih kebijakan akuntansi dan prosedur akuntansi tertentu bertujuan memaksimumkan utility manajer dan harga saham yang disebut manajemen laba (Earning Management).

Secara garis besar Healy (1985) menyatakan bahwa penggunaan transaksi discretionary accruals, manajemen dapat mempengaruhi laba dengan mengendalikan jumlah taksiran akuntansi. Contoh transaksi discretionary accruals yaitu menaksir jumlah piutang tidak tertagih diturunkan dari tahun sebelumnya sehingga jumlah piutang netto akan naik, dengan asumsi pendapatan tetap maka laba tahun ini akan relatif tinggi. Selain itu adanya perubahan taksiran umur ekonomis aktiva tetap atau amortisasi aktiva tidak berwujud. Proses yang dilakukan oleh manajemen tersebut dengan cara menggeser perioda biaya atau pendapatan sehingga manajemen dapat memperoleh keuntungan dibalik perubahan yang dilakukannya.

H8: Terdapat hubungan positif yang signifikan antara manajemen laba dengan initial return

\section{Initial Return}

Dalam menginvestasikan dana yang dimilikinya harapan yang diinginkan oleh investor adalah memperoleh hasil dari yang investasinya. Hasil yang diperoleh dari investasi dalam bentuk saham adalah yang disebut dengan return dalam hal ini yang dimaksud adalah initial return. Semakin besar initial return yang dihasilkan suatu saham maka akan lebih manerik bagi investor untuk dimiliki sehingga dari berbagai penelitian return sebagai ukuran kinerja perusahaan (Jogiyanto, 1998)

Seperti ditulis oleh Jones (1996) bahwa return dapat berupa return realisasi yaitu return yang sudah terjadi, initial return atau return awal dan return ekspektasi yaitu return yang diharapkan akan diperoleh investor dimasa yang akan datang. Sedangkan komponen return itu sendiri terdiri dari deviden dan capital gain/losses. 


\section{METODOLOGI PENELITIAN}

\section{Populasi}

Populasi dalam penelitian ini adalah seluruh perusahaan go public yang telah terdaftar di Bursa Efek Indonesia yang melakukan penawaran umum perdana atau IPO. Sampai dengan periode pengamatan tahun 2007.

\section{Sampel}

Sampai dengan periode pengamatan tahun 2007, dari jumlah tersebut diambil untuk sampel adalah perusahaan yang melakukan IPO tahun 2005 dan 2007 dengan kriteria underpricing. Adapun teknik pengambilan sampel dengan Purposive Sampling. Diambil dari periode pengamatan tersebut saham yang underpricing dan yang memenuhi kelengkapan data.

\section{Data yang Digunakan}

Data yang digunakan adalah data sekunder, data diperoleh dari Directory Of Capital Market 2000 yang berisi informasi prospektus seluruh perusahaan go public sampai tahun 2000. Data yang diperlukan adalah sebagai berikut :

1. Harga saham perusahaan yang melakukan IPO tahun 2005-2007 saat penawaran umum maupun saat penutupan hari pertama listing untuk menentukan nilai initial return

2. Prospektus dari seluruh perusahaan yang melakukan IPO tahun 2005-2007 untuk mengetahui nama auditor yang mengaudit laporan keuangan, nama penjamin emisi yang melakukan penjaminan emisi saham, umur perusahaan, prosentase saham yang ditawarkan pada publik, sektor industri dan informasi keuangan untuk menghitung ROA, Financial leverage dan manajemen laba.

\section{Pengukuran Variabel}

Variabel dependen adalah initial return sedangkan variabel independennya adalah reputasi auditor, reputasi penjamin emisi (underwriter), prosentase penawaran saham saat IPO, umur perusahaan, profitabilitas perusahaan, financial leverage, sektor industri dan manajemen laba (merupakan variabel laten). Diduga bahwa variabel independen dan variabel laten berpengaruh signifikan terhadap variabel dependen, dalam hal ini kedudukan variabel laten 
sama dengan variabel independen, untuk mengetahui besarnya nilai yang ada dalam variabel laten maka perlu diobservasi terlebih dahulu, proxy yang digunakan untuk meneliti variabel laten (manajemen laba) adalah total accruals dengan discretionary accruals

\section{Pengukuran Variabel Independen}

\section{Reputasi Auditor}

Untuk menentukan reputasi auditor dibuatkan record dari perusahaan yang go public tahun 2005-2007 dan membuat urutan sesuai dengan urutan yang telah ditetapkan BAPEPAM berdasarkan kredibilitas hasil auditnya dan frekuensi auditor melakukan audit terhadap laporan keuangan perusahaan go public. Asumsinya bila emiten menggunakan auditor yang termasuk dalam kategori big-four diberikan angka 1 dan sebaliknya bila diluar kategori big-four diberi angka 0.

\section{Reputasi Penjamin Emisi}

Ukuran reputasi penjamin emisi yang digunakan dalam penelitian ini adalah rangking penjamin emisi versi tim litbang majalah GEMPITA, sesuai dengan indikator yang digunakan dalam tim litbang majalah GEMPITA maka dalam menentukan reputasi penjamin emisi ini diberi skala 1 untuk penjamin emisi yang prestigious yaitu urutan pertama sampai dengan kelima dan skala 0 untuk penjamin emisi yang non prestigious (Hayes,1987 dalam Trisnawati, 1998). Sesuai dengan indikator majalah GEMPITA ini maka emiten yang menggunakan penjamin emisi The big-four (rangking 1-5 dari urutan penjamin emisi) diberi skala 1 dan bila emiten menggunakan penjamin emisi Non The big-four diberi skala 0

\section{Umur Perusahaan}

Pengukuran variabel ini berdasarkan lamanya perusahaan tersebut beroperasi yaitu sejak didirikan sampai dengan saat penawaran umum (tahun), karena pertimbangan peneliti adalah semakin lama perusahaan beroperasi maka akan semakin banyak memiliki informasi dibandingkan dengan perusahaan yang baru beroperasi. Informasi inilah yang dibutuhkan oleh investor dalam menentukan investasi yang akan dilakukan.

\section{Prosentase Saham yang Ditawarkan}

Diukur berdasarkan besarnya prosentase saham yang dijual kepada masyarakat saat IPO. Prosentase saham menunjukkan banyaknya informasi yang diungkapkan oleh perusahaan maka semakin besar saham yang ditawarkan akan semakin besar pula kandungan informasinya. 


\section{Rate of Return on Asset (ROA) atau Profitabilitas Perusahaan}

ROA diukur dari net income terhadap total asset. Profitabilitas merupakan kemampuan perusahaan untuk menghasilkan laba. Jika profitabilitasnya tinggi maka prospek perusahaan akan tinggi dan investor akan cenderung menanamkan modalnya

\section{Financial Leverage}

Rasio leverage diukur dari total hutang terhadap total asset. Rasio ini menunjukkan risiko yang dihadapi oleh perusahaan jika rasio leverage tinggi maka risiko yang akan ditanggung juga tinggi. Informasi ini sangat penting bagi investor untuk dipertimbangkan dalam penanaman investasi

\section{Sektor Industri}

Ada dua model perusahaan yaitu manufaktur dengan memberikan skala 1 dan non manufaktur dengan memberikan skala 0

\section{Manajemen Laba}

Pengukuran yang digunakan oleh Gumanti (2000) menggunakan uji T terhadap total accruals sebagai proxy dari discretionary accruals dengan masa 2 tahun sebelum IPO dan 1 tahun sebelum IPO, jika hasil prosentese positif discretionary accruals lebih tinggi dari hasil prosentase negatif discretionary accruals berarti praktik manajemen laba tinggi dan diberi bobot 1 . Sedangkan apabila hasil prosentase positif dicretionary accruals lebih kecil dari hasil prosentase negatif discretionary accruals berarti praktik manajemen laba kecil dan diberi bobot 0 .

$$
\mathrm{TAC}_{\mathrm{t}}=\mathrm{NI}_{\mathrm{t}}-\mathrm{CFO}_{\mathrm{t}}
$$

Dimana $\mathrm{TAC}_{\mathrm{t}}$ adalah total accruals pada periode ke-t, $\mathrm{NI}_{\mathrm{t}}$ adalah net income (laba bersih sebelum pajak) yang juga income before extraordinary items pada periode ke-t dan $\mathrm{CFO}_{\mathrm{t}}$ adalah cash flow from operating activity pada periode ke-t

$$
\mathrm{DAC}_{\mathrm{pt}}=\left(\mathrm{TAC}_{\mathrm{pt}} / \mathrm{SALE}_{\mathrm{pt}}\right)-\left(\mathrm{TAC}_{\mathrm{pd}} / \mathrm{SALE}_{\mathrm{pd}}\right) \ldots \ldots \ldots \ldots \ldots \ldots \ldots
$$

Dimana $\mathrm{DAC}_{\mathrm{pt}}$ adalah discretionary accruals pada periode tes, $\mathrm{TAC}_{\mathrm{pt}}$ adalah total accruals pada periode tes, $\mathrm{SALE}_{\mathrm{pt}}$ adalah penjualan pada periode tes, $\mathrm{TAC}_{\mathrm{pd}}$ adalah total accruals pada periode dasar dan $S_{A L E}$ adalah penjualan pada periode dasar

\section{Pengukuran Variabel Dependen}

\section{Initial Return}


Variabel dependen ini diukur dari selisih antara harga penawaran umum dengan harga jual saham pertama kali di pasar sekunder.

$$
\text { Initial Return }=\frac{(\text { Initial market price }- \text { Issue price })}{\text { Issue price }} \ldots \ldots \ldots \ldots . . . . . .
$$

\section{Analisis Pengolahan Data dan Pengujian Hipotesis}

Metode analisis yang digunakan untuk menguji hipotesis adalah multiple regression yaitu untuk menguji kekuatan hubungan antara intial return dengan reputasi auditor, reputasi penjamin emisi, prosentase saham yang ditawarkan saat IPO, profitabilitas, financial leverage dan manajemen laba. Program analisis menggunakan SPSS.

Untuk menguji hubungan antara initial return (variabel dependen) dengan variabel independennya sebanyak 8 digunakan model sebagai berikut

$$
\begin{aligned}
& \mathrm{IR}_{\mathrm{i}, \mathrm{t}}=\mathbf{a}+\mathrm{b}_{1} \mathrm{AUDT}_{\mathrm{i}, \mathrm{t}}+\mathrm{b}_{2} \mathrm{IBANK}_{\mathrm{i}, \mathrm{t}}+\mathrm{b}_{3} \mathrm{AGE}_{\mathrm{i}, \mathrm{t}}+\mathrm{b}_{4} \mathrm{OFFER}_{\mathrm{i}, \mathrm{t}}+\mathrm{b}_{5} \mathrm{ROA}_{\mathrm{i}, \mathrm{t}}+\mathrm{b}_{6} \mathrm{LEV}_{\mathrm{i}, \mathrm{t}}+\mathrm{b}_{7} \mathrm{IND}_{\mathrm{i}, \mathrm{t}}+
\end{aligned}
$$

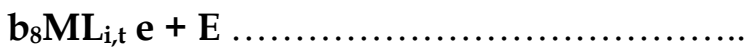

\begin{tabular}{|c|c|}
\hline $\mathrm{IR}_{\mathrm{i}, \mathrm{t}}$ & $=$ initial return \\
\hline $\mathrm{AUDT}_{\mathrm{i}, \mathrm{t}}$ & $=$ reputasi auditor \\
\hline IBANK $_{i, t}$ & $=$ reputasi penjamin emisi (underwriter) \\
\hline $\mathrm{AGE}_{\mathrm{i}, \mathrm{t}}$ & $=$ umur perusahaan \\
\hline OFFER $_{i, t}$ & $=$ prosentase saham yang ditawarkan \\
\hline $\mathrm{ROA}_{\mathrm{i}, \mathrm{t}}$ & $=$ rate of return on asset \\
\hline $\mathrm{LEV}_{\mathrm{i}, \mathrm{t}}$ & $=$ financial leverage \\
\hline $\mathrm{IND}_{\mathrm{i}, \mathrm{t}}$ & $=$ sektor industri \\
\hline $\mathrm{ML}_{\mathrm{i}, \mathrm{t}}$ & $=$ manajemen laba \\
\hline E & $=$ error \\
\hline
\end{tabular}

Penjelasan model di atas adalah sebagai berikut ini :

\section{ASUMSI KLASIK}

Uji Normalitas

Uji normalitas dapat diketahui dari hasil Kolmogorof-Smirnov test, jika nilai $\mathrm{p}>\mathrm{a}(\mathrm{a}=5 \%)$ maka data terdistribusi normal, sebaliknya apabila $\mathrm{p}<\mathrm{a}$ kemungkinan besar data tidak terdistribusi normal. Apabila data yang digunakan mencukupi standar kebutuhan sampel, kemungkinan besar normalitas datanya akan baik. Beaver (1992) menggunakan asumsi Central 
Limit Theorm dimana menyatakan bahwa apabila sampel yang digunakan cukup besar $(\mathrm{n}>30)$, distribusi sampling ditaksir mendekati normal.

\section{Otokorelasi}

Merupakan asumsi penting dari model linier klasik adalah tidak adanya otokorelasi atau kondisi yang berurutan diantara gangguan atau disturbansi ui atau ei yang masuk ke dalam fungsi regresi (Gujarati,1991:201). Uji yang digunaan untuk mendeteksi adanya otokorelasi ini adalah uji Durbin Watson. Dengan menggunakan program SPSS dapat dilihat nilai Durbin Watson tersebut. Jika nilai Durbin Watson lebih kecil dibandingkan nilai teoritisnya menunjukkan adanya otokorelasi.

\section{Multikolinieritas}

Metode yang digunakan untuk menguji adanya multikolinieritas ini dapat dilihat dari tolerance value atau variance inflations factor (VIF), batas dari tolerance value adalah 0.10 dan batas VIF adalah 10 (Hair et.al, 1995 dalam Trisnawati,2000). Jika nilai tolerance value dibawah 0.10 atau nilai VIF diatas 10 maka terjadi multikolinieritas

\section{Heteroskedastisitas}

Salah satu cara yang digunakan untuk mendeteksi adanya heteroskedastisitas adalah menggunakan Sperman Rank Correlation. Dengan menggunakan program SPSS dapat diketahui korelasi variabel independen dengan nilai residual (Res-1). Apabila nilai korelasi variabel independen dalam model dengan nilai residu kurang dari 0.7 maka tidak terjadi heteroskedastisitas.

\section{ANALISIS DAN HASIL PENELITIAN ASUMSI KLASIK}

Model yang digunakan adalah regresi berganda, sehingga harus dipenuhi asumsiasumsi klasik agar analisis yang dilakukan bisa dikatakan reliabel. Asumsi-asumsi yang diperlukan meliputi normalitas, autokorelasi, multikolinieritas dan heteroskedastisitas.

4.1 Tabel Hasil Uji Normalitas, Autokorelasi dan Multikolinieritas

\begin{tabular}{|l|l|l|l|}
\hline VARIABEL & TOLERANCE & VIF & K-SMIRNOF \\
\hline \hline
\end{tabular}




\begin{tabular}{|l|l|l|l|}
\hline \hline AUDT & 0.919 & 1.089 & 2.929 \\
\hline IBANK & 0.910 & 1.098 & 3.208 \\
\hline AGE & 0.885 & 1.130 & 0.722 \\
\hline OFFER & 0.889 & 1.125 & 0.811 \\
\hline LEV & 0.930 & 1.075 & 0.822 \\
\hline ROA & 0.812 & 1.232 & 0.581 \\
\hline IND & 0.964 & 1.037 & 3.277 \\
\hline EM & 0.850 & 1.177 & 2.717 \\
\hline \hline \multicolumn{2}{|l|}{ Durbin-Watson:1.931 } & \\
\hline
\end{tabular}

\section{Uji Normalitas}

Dari hasil analisis diketahui bahwa data yang digunakan terdistribusi normal. Hal ini dapat dilihat dari nilai Kolmogorof-Smirnov test, jika nilai $\mathrm{p}>\mathrm{a}(\mathrm{a}=5 \%)$ maka data terdistribusi normal, sebaliknya apabila $\mathrm{p}<\mathrm{a}$ kemungkinan besar data tidak terdistribusi normal.

Apabila data yang digunakan mencukupi standar kebutuhan sampel, kemungkinan besar normalitas datanya akan baik. Pada penelitian ini, hasil dari uji normalitas didapat data terdistribusi normal. Artinya banyaknya sampel yang di gunakan dalam penelitian cukup besar $(\mathrm{n}>30)$. Beaver (1992) menggunakan asumsi Central Limit Theorm dimana menyatakan bahwa apabila sampel yang digunakan cukup besar $(n>30)$, distribusi sampling ditaksir mendekati normal.

\section{Uji Autokorelasi}

Untuk mendeteksi adanya autokorelasi dapat dilihat dari nilai Durbin Watson. Nilai Durbin Watson dari penelitian menunjukkan angka 1.931 yang berarti lebih besar dari nilai 
teoritisnya yaitu sebesar 1.634, sehingga tidak terjadi autokorelasi. Dengan demikian model yang digunakan dalam penelitian cukup reliabel untuk dasar analisis

\section{Uji Multikolinieritas}

Multikolineritas berarti ada hubungan linier yang sempurna atau pasti diantara beberapa atau semua variabel yang independen dari model yang ada (Gujarati, 1995). Akibat dari adanya multikolinieritas ini adala koefisien regresinya tidak tertentu atau kesalahan standarnya tidak terhingga. Hal ini akan menimbulkan bias dalam spesifikasi.

Metode yang digunakan untuk menguji adanya multikolieritas ini dapat dilihat dari tolerance value dan variance inflation factor (VIF). Batas dari tolerance value adalah $\mathrm{p}>0.10$ dan batas VIF adalah p<10 (Hair et.al, 1995). Jika nilai tolerance value kurang dari ketentuan diatas berarti terjadi multikolinieritas

\section{Uji Heteroskedastisitas}

Untuk mendeteksi adanya heteroskedastisitas digunakan matrik korelasi Rank Spearman. Dari hasil analisis pada Tabel 4.2 terlihat bahwa semua variabel independen memiliki nilai koefisien korelasi dengan nilai mutlak residualnya menunjukkan nilai yang relatif kecil. Young seperti yang dikutip oleh Djarwanto (1985) heteroskedastisitas akan menjadi permasalahan bila koefisien matrik korelasi Rank Spearman melebihi 0.7

Tabel 4.2 Hasil Uji Heteroskedastisitas (Matrik Korelasi Rank Spearman)

\begin{tabular}{|l|r|r|r|r|r|r|r|r|l|}
\hline & \multicolumn{1}{|l|}{ RES } & AUDT & IBANK & AGE & OFFE & LEV & ROA & IND & EM \\
\hline RES & 1.000 & & & & & & & & \\
\hline AUDT & 0.200 & 1.000 & & & & & & & \\
\hline IBANK & -0.306 & 0.173 & 1.000 & & & & & & \\
\hline AGE & -0.239 & 0.002 & 0.090 & 1.000 & & & & & \\
\hline LFFER & 0.061 & -0.209 & -0.091 & -0.012 & 1.000 & & & & \\
\hline ROA & 0.133 & -0.137 & -0.069 & -0.025 & 0.223 & 1.000 & & & \\
\hline IND & -0.039 & -0.106 & -0.087 & 0.284 & 0.057 & 0.018 & 1.000 & & \\
\hline EM & 0.126 & -0.029 & -0.139 & 0.014 & 0.017 & 0.085 & 0.073 & 1.000 & \\
\hline
\end{tabular}




\subsection{ANALISIS DATA}

Jumlah perusahaan yang melakukan IPO dari tahun 2005 sampai dengan 2007 sebanyak 76 perusahaan manufaktur dan non manufaktur. Teknik pengambilan sampel dengan purposive sampling yaitu pertama harga saham pada saat IPO harus underpricing artinya harga saat penawaran perdana lebih rendah dibandingkan dengan harga saham pada saat dijual dipasar sekunder, kedua laporan prospektus perusahaan yang akan melakukan IPO memenuhi kelengkapan data baik data keuangan maupun data non keuangan.

Tabel 4.3 Sampel Penelitian

\begin{tabular}{|l|r|}
\hline \multicolumn{1}{|c|}{ NAMA } & JUMLAH \\
\hline \hline Perusahaan yang melakukan IPO tahun 2005- & 76 \\
2007 & \\
\hline Tidak Underpricing & 14 \\
\hline Data tidak memenuhi kelengkapan & 9 \\
\hline Jumlah Sampel & 53 \\
\hline
\end{tabular}

Tabel 4.4 Deskripsi Data

\begin{tabular}{|l|r|r|r|r|r|}
\hline VARIABEL & MAX & MIN & MEAN & SE.MEAN & ST.DEV \\
\hline IR & 6.1738 & 1.3471 & 3.8892 & 0.1571 & 1.1439 \\
\hline AUDT & 1 & 0 & 0.62 & 0.0672 & 0.49 \\
\hline IBANK & 1 & 0 & 0.30 & 0.0637 & 0.46 \\
\hline AGE & 3.8067 & 1.0986 & 2.2448 & 0.0944 & 0.6869 \\
\hline OFFER & 3.912 & 1.8976 & 3.1078 & 0.0659 & 0.4802 \\
\hline LEV & 12.1194 & 0 & 4.4506 & 0.2835 & 2.0642 \\
\hline ROA & 5.8289 & -1.5141 & 1.4009 & 0.1959 & 1.4263 \\
\hline IND & 1 & 0 & 0.28 & 0.0625 & 0.45 \\
\hline EM & 1 & 0 & 0.57 & 0.0687 & 0.50 \\
\hline
\end{tabular}

\section{PENGUJIAN HIPOTESIS}


Data dianalisis dengan menggunakan regresi berganda untuk mengetahui kekuatan hubungan antara variabel reputasi auditor, reputasi penjamin emisi, umur perusahaan, prosentase saham yang ditawarkan ke masyarakat, ROA, financial leverage, manajemen laba terhadap initial return

Tabel 4.5 Hasil Analisis

\begin{tabular}{|l|r|r|r|l|}
\hline \multicolumn{1}{|c|}{ VARIABEL } & Koef.BETA & t-VALUE & \multicolumn{1}{|c|}{ SIGNIF } & KETERANGAN \\
\hline \hline IR & 3.567 & 3.052 & $0.004^{*}$ & Didukung \\
\hline AUDT & 0.677 & 2.155 & $0.037^{*}$ & H1 Didukung \\
\hline IBANK & -0.69 & -2.071 & $0.044^{*}$ & H2 Didukung \\
\hline AGE & -0.303 & -1.328 & 0.191 & H3 Tidak didukung \\
\hline OFFER & 0.224 & 0.687 & 0.495 & H4 Tidak didukung \\
\hline ROV & 0.0767 & 1.036 & 0.306 & H5 Tidak didukung \\
\hline IND & -0.0415 & -0.362 & 0.719 & H6 Tidak didukung \\
\hline EM & 0.245 & 0.741 & 0.463 & H7 Tidak didukung \\
\hline Signif F 0.065** & -0.473 & -1.481 & 0.146 & H8 Tidak didukung \\
\hline *signifikan pada level 5\% & & & & \\
\hline
\end{tabular}

Hasil uji korelasi antara masing-masing variabel independen dengan variabel dependennya dapat dilihat pada tabel berikut ini

Tabel 4.6 Matrik Korelasi

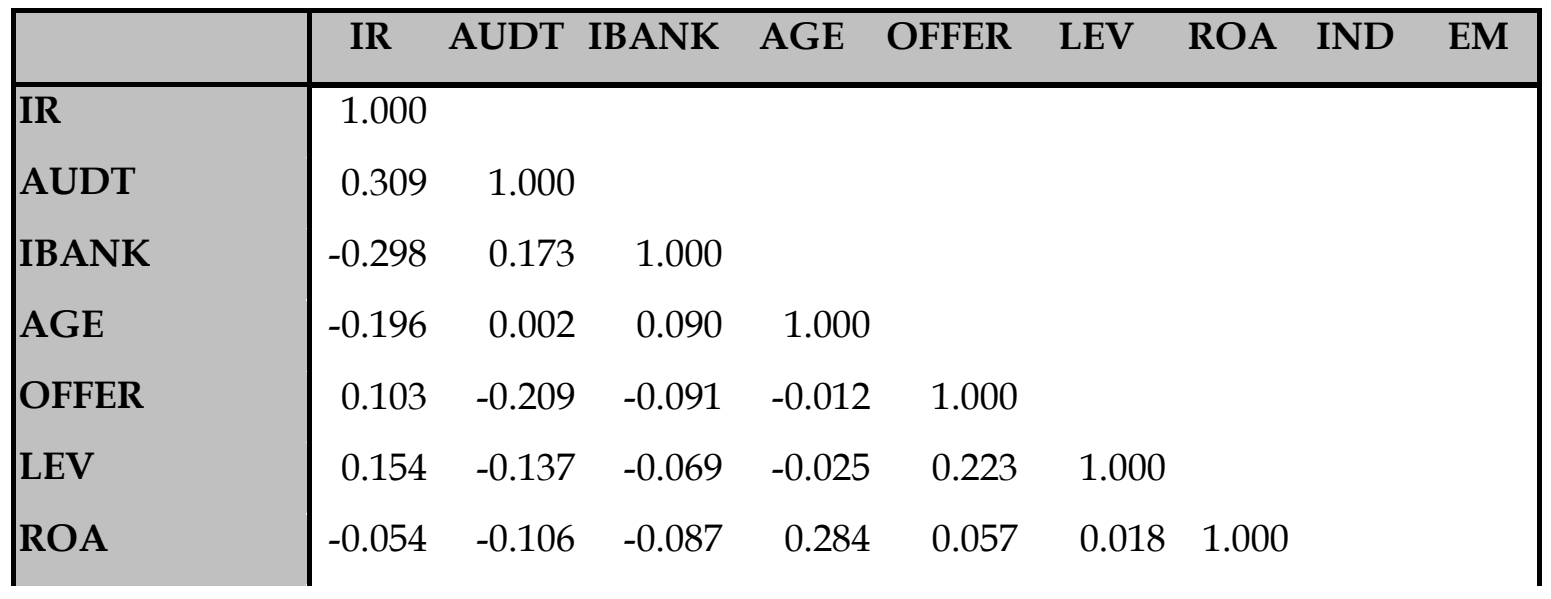




\begin{tabular}{|l|rrrrrrrrr|} 
IND & 0.111 & -0.029 & -0.139 & 0.014 & 0.017 & 0.085 & 0.073 & 1.000 & \\
EM & -0.214 & 0.025 & 0.161 & 0.070 & 0.143 & 0.088 & -0.268 & 0.043 & 1.000 \\
\hline
\end{tabular}

Analisis masing-masing variabel menghasilkan bahwa untuk (H1) yaitu reputasi auditor mempunyai nilai signifikan $\mathrm{T}$ sebesar 0.037 yang berarti lebih kecil dari tingkat signifikan 5\% sehingga disimpulkan bahwa berhasil menunjukkan pengaruh yang signifikan antara variabel reputasi penjamin emisi terhadap initial return. Nilai koefisien regresi sebesar 0.677 dengan koefisien korelasi sebesar 0.309, tingginya nilai koefisien korelasi sebesar 30.9\% menunjukkan variabel ini signifikan dalam mempengaruhi initial return di pasar modal Indonesia selama tahun 2005 sampai dengan tahun 2007.

Reputasi penjamin emisi pada $\mathrm{H} 2$ mempunyai nilai signifikan T sebesar 0.044 , sehingga dapat disimpulkan bahwa pada hipotesis ini berhasil menunjukkan pengaruh yang signifikan antara reputasi penjamin emisi dengan initial return. Nilai koefisien regresi sebesar -0.690 dan nilai koefisien korelasinya sebesar -0.298 . Hal ini berarti reputasi penjamin emisi dapat menjelaskan hubungan negatif yang kuat terhadap initial return yaitu sebesar 29.8\%

Umur perusahaan pada H3 mempunyai nilai signifikansi T sebesar 0.191, angka tersebut mengandung arti bahwa umur perusahaan tidak mempunyai pengaruh yang signifikan terhadap initial return didukung oleh nilai koefisien regresi sebesar -0.303 dan nilai koefisien korelasi sebesar -0.196. Hal ini berarti umur perusahaan dapat menjelaskan hubungan negatif yang kuat terhadap initial return yaitu sebesar 19.6\%

Persentase saham yang ditawarkan pada $\mathrm{H} 4$ mempunyai nilai signifikansi $\mathrm{T}$ sebesar 0.495, yaitu lebih besar dari nilai signifikansi 5\%. Artinya hipotesis ini tidak berhasil menunjukkan pengaruh yang signifikan variabel prosentase saham yang ditawarkan terhadap initial return. Nilai koefisien regresi sebesar 0.224 dan koefisien korelasi sebesar 0.103 . hal ini berarti variabel prosentase penawaran saham hanya dapat menjelaskan secara parsial initial return sangat lemah yaitu $10.3 \%$

Profitabilitas perusahaan (ROA) pada H5 mempunyai nilai signifikansi T sebesar 0.719 kesimpulan yang dapat diberikan adalah tidak berhasil menunjukkan hubungan yang signifikan antara profitabilitas perusahaan dalam hal ini ROA terhadap initial return. Nilai koefisien regresi sebesar -0.0415 dan nilai koefisien korelasinya sebesar -0.054 , hubungan yang ditunjukkan adalah negatif antara ROA dengan initial return sebesar $5.4 \%$ 
Financial leverage pada H6 mempunyai nilai signifikansi T sebesar 0.306, kesimpulan yang dapat diberikan adalah bahwa tidak berhasil menunjukkan hubungan yang signifikan antara financial leverage terhadap initial return. Nilai koefisien regresi menunjukkan angka sebesar 0.0767 dan nilai koefisien korelasi menunjukkan angka sebesar 0.154, menunjukkan hubungan negatif signifikan sebesar $15.4 \%$ antara financial leverage dengan initial return.

Sektor industri pada H7 mempunyai nilai signifikansi T sebesar 0.463 . Artinya sektor industri tidak berhasil menunjukkan pengaruh yang signifikan terhadap initial return. Nilai koefisien regresi sebesar 0.245 dan nilai koefisien korelasi sebesar 0.111 , variabel sektor industri hanya dapat menjelaskan secara parsial initial return lemah yaitu sebesar $11.1 \%$

Manajemen laba pada H8 nilai yang ditunjukkan signifikansi T sebesar 0.146, berarti hipotesis kedelapan tidak berhasil menunjukkan pengaruh yang signifikan terhadap initial return. Nilai koefisien regresi sebesar -0.473 dan nilai koefisien korelasi sebesar -0.218 . hal ini berarti variabel manajemen laba hanya dapat menjelaskan secara parsial initial return sangat lemah yaitu $21.8 \%$

Secara keseluruhan model yang digunakan untuk menguji hipotesis cukup reliabel dengan dibuktikan nilai signifikan F sebesar 0.041. dengan demikian variasi variabel independen dapat menjelaskan variasi variabel dependennya. Variabel independen yang digunakan dalam model dapat menjelaskan variabel dependen sebesar $27 \%$ yang ditunjukkan oleh besarnya R-Square 0.270 .

\section{PEMBAHASAN}

Penelitian ini berhasil menunjukkan bahwa dewasa ini investor lebih menekankan pada informasi non keuangan sebagai salah satu sumber informasi yang reliabel untuk berinvestasi di dunia pasar modal Indonesia. Hal ini terbukti dari hasil signifikansi T pada variabel reputasi auditor dan reputasi penjamin emisi mempunyai nilai $\mathrm{p}<0.10$. Artinya investor di pasar modal Indonesia dewasa ini lebih memperhitungkan non keuangan sebagai informasi penting dalam mengambil kebijakan berinvestasi.

Nilai signifikansi T untuk reputasi auditor adalah 0.037 yang berarti signifikan pada $\alpha$ $5 \%$. Sedangkan hasil uji korelasi menunjukkan bahwa variabel reputasi penjamin emisi dapat menjelaskan initial return sebesar 0.200 atau sebesar $20 \%$ yang berhubungan positif terhadap initial return. Hasil ini mendukung penelitian yang telah dilakukan oleh Balvers (1998) yaitu reputasi auditor dan reputasi penjamin emisi berpengaruh negatif signifikan terhadap initial 
return. Baetty (1989) bahwa reputasi auditor, reputasi penajmin emisi, prosentase penawan saham, umur perusahaan, tipe penjamin emisi dan indikator perusahaan berpengaruh positif signifikan terhadap initial return.

Nilai signifikansi T untuk reputasi penjamin emisi adalah 0.044 yang berarti signifikan pada $\alpha=5 \%$. Hasil pengujian korelasinya menunjukkan bahwa variabel reputasi penjamin emisi dapat menjelaskan initial return -0.306 atau sebesar $30.6 \%$ yang berhubungan negatif terhadap initial return. Hasil penelitian ini mendukung penelitian yang dilakukan oleh Daljono (2000) dan Sundari (1993) yang menyimpulkan bahwa reputasi penjamin emisi berpengaruh negatif signifikan terhadap initial return. Carter dan Dark (1992) menghasikan bahwa reputasi penjamin emisi, prosentase penawaran saham, umur perusahaan berpengaruh negatif signifikan terhadap initial return. Carter dan Manaster (1990) menghasilkan bahwa The lower risk offering dijamin oleh penjamin emisi yang bereputasi

Implikasi hasil penelitian ini berati bahwa ada dua informasi utama yang bermanfaat bagi investor di pasar perdana yaitu reputasi auditor dan reputasi penjamin emisi. Sedangkan informasi lain yang terkandung dalam laporan prospektus yaitu umur perusahaan, prosentase saham yang ditawarkan ke masyarakat, ROA, financial leverage, sektor industri dan manajemen laba bukan lagi menjadi sumber informasi terpenting bagi investor untuk berinvestasi di pasar modal Indonesia, khususnya saat pasar perdana. Hal ini kemungkinan karena investor di pasar perdana menggunakan sumber informasi lain selain informasi prospektus dalam pengambilan keputusan berinvestasi.

\section{KESIMPULAN}

Penelitian ini bertujuan untuk menguji pengaruh informasi prospektus terhadap initial return. Prospektus merupakan informasi yang disediakan oleh perusahaan untu digunakan investor dalam menilai prospek dan risiko suatu perusahaan. Dalam laporan prospektus terdapat informasi non keuangan dan informasi keuangan meliputi informasi auditor yang mengaudit laporan keuangan, underwriter sebagai penjamin saham yang ditawarkan, banyaknya saham yang ditawarkan kepada publik, umur perusahaan yaitu lama perusahaan itu berdiri sampai go public, sektor industri dan laporan keuangan perusahaan. Laporan keuangan yang dimuat dalam laporan prospektus umumnya berkisar antara satu hingga tiga periode akuntansi, didalamnya memuat informasi keuangan antara neraca, laporan laba rugi, laporan perubahan modal, laporan arus kas dan rasio keuangan (financial leverage, ROA) 
Berdasarkan analisis yang dilakukan menunjukkan bahwa variabel independen yang berpengaruh signifikan terhadap initial return adalah reputasi auditor dan reputasi penjamin emisi. Nilai signifikan T masing-masing adalah untuk reputasi auditor (AUDT) sebesar 0.037 dengan nilai koefisien regresi sebesar 0.677 , hasil koefisien regresi positif menunjukkan adanya hubungan searah antara reputasi auditor dengan initial return. Untuk reputasi penjamin emisi mempunyai nilai signifikansi T sebesar 0.044 dengan nilai koefisien regresi sebesar -0.690 , hasil koefisien regresi negatif menunjukkan hubungan berbalik antara reputasi penjamin emisi dengan initial return.

Dari hasil analisis secara keseluruhan menunjukkan bahwa informasi non keuangan dan informasi keuangan yang terdapat dalam laporan prospektus tidak berpengaruh signifikan terhadap initial return. Hal ini dapat disimpulkan dari hasil pengujian yang menunjukkan sebagian besar variabel independen tidak signifikan. Dengan hasil tersebut mengindikasikan bahwa informasi prospektus yang diberikan oleh perusahaan pada saat IPO tidak digunakan oleh investor dalam pengambilan keputusan.

\section{Keterbatasan dan Saran}

Beberapa hal yang menjadi keterbatasan dalam penelitian ini dan beberapa saran yang perlu diperhatikan untuk menyempurnakan penelitian yang akan datang, dan dapat menjadikan ide baru dalam melakukan penelitian di pasar modal khususnya.

1. Rentang waktu yang digunakan sangat pendek, sehingga sampel yang digunakan sangat terbatas, jika sampel mencukupi maka validitas hasil akan semakin baik, khususnya untuk validitas variabel independen manajemen laba.

2. Manajemen laba hanya digunakan sebagai variabel independen, karena pada penelitian ini lebih berfokus pada initial return, bagi peneliti yang akan datang dapat mengangkat manajemen laba sebagai variabel dependen yang dihubungkan dengan faktor etika Indonesia.

3. Informasi prospektus yang digunakan hanya financial leverage dan ROA. Implikasi bagi peneliti selanjutnya adalah perlu dilakukan penelitian lebih lanjut mengenai pengaruh informasi akuntansi dengan menggunakan rasio-rasio yang lain. 




\section{DAFTAR PUSTAKA}

Aggarwal.R.,R.Leal dan L.Hernandez, 1993,The After Market Performance of Initial Public Offering in Latin America, Financial Management, spring 1993: pp.42-53

Balvers.R, McDonal dan RE Miller, 1988, Underpricing of New Issues and the Choice of Auditor as a Signal of Investment Banker Reputation, The Accounting Review 63 (Oktober): 602-622

Baron.DP, 1982, A Model of The Demand For Investment Banking Advising and Distributions Services For New Issues, Journal of Finance 37: pp. 955-976

Beatty.R.P, 1989, Auditor Reputations and The Pricing of Initial Public Offerings, The Accounting Review vol LXIV no 4 October, pp. 693-707

Beatty. R. P dan J. Ritter, 1986, Invesment Banking, Reputation, and The Underpricing of Initial Public Offering, Journal of Financial Economics, Jan/Feb, pp. 213-232

Bringham. Eugene F. dan Louis C. Gapenski., 1993, Intermediate Financial Management, Fourth Editions. New York: The Dryden Press.

Cahan. S. F, 1992, The Effect Of Antitrust Investigations on Discretionary Accruals: A Refined Test Of Political-Cost Hypothesis, The Accounting Review, 67 (1), pp. 77-95

Christy. MI. Hasan dan SD.Smith, 1996, A Note on Underwriter Competition and Initial Public Offering, Journal of Bussiness Finance And Accounting 23 May and June; 905-914

Carter, R. dan S. Manaster, 1990, Initial Public Offering and Underwriter Reputation, Journal of Financial , Vol XLV No. 4, pp. 1045-1067

Carter. R.B, F.H. Dark dan Ajai K. Singh, 1998, Underwriter Reputation, Initial Returns, and The Long Run Performance of IPO Stocks, The Journal of Finance, Vol. LIII No. 1, February, pp. 258-311

Daljono, Analisis Faktor-Faktor Yang Memperngaruhi Initial Return Saham Yang Listing Di BEJ Tahun 1990-1997, Makalah Simposium Nasional Akuntansi III, 2000

DeAngelo.L.E. 1988. Accounting Number as Valuations Substitutes: A Study of Management Buyouts of Public Stockholders. The Accounting Review, 59: 400-420

Firth. Michael dan Chee Keng Liau-Tan, 1998, Auditor Quality, Signaling and The Valuation of Initial Public Offering, Journal of Business Finance $\mathcal{E}$ Accounting, 25 (1) \& (2), Jan/ March, pp. 145-165 
Firth. Michael dan A. Smith, 1992, The Accuracy of Profits Forecasts in Initial Public Offerings Prospektus, Accounting and Business Research, Vol. 22 No. 87, pp. 239-247

Gujarati. Damodar, 1995, Basic Econometrics, 3 ${ }^{\text {rd }}$ edition,McGraw-Hill

Gumanti. A. Tatang, Earning Management dalam Penawaran Saham Perdana Di BEJ, Makalah Simposium Nasional Akuntansi III, 2000

Hendrayati. Sri, 1994, Pengaruh Informasi Akuntansi Terhadap Pengambilan Keputusan Investor di Pasar Perdana Pasar Modal Indonesia, Tesis-S2, tidak dipublikasikan

Healy. P.M dan James M. Wahlen, 1998, A Review of The Earnings Management Literature and Implications for Standard Setting, Journal Accounting Research

Healy. P.M, 1985, The Effec of Bonus Schemes on Accounting Decisions, Journal of Accounting and Economics, Vol. 10, pp. 85-107

Husnan. Suad (1996), Penjualan Saham BUMN: Apakah Terjadi Distribusi Kemakmuran ?, Kelola No 13 Mei,p.62-74

Jogiyanto, 1998, Teori Portofolio dan Analisis Investasi, edisi pertama, BPFE, Yogyakarta

Jones. Charles P., 1996, Invesment : Analysis and Management, New York, John Wiley and Sons Inc

Jones. J, 1991, Earning Management During Import Relief Investigations, Journal of Accounting Research Vol. 29 No. 2 Autumn, pp. 193-228

Juanda.Ahmad, Earning Management dan Kinerja Saham Perusahaan Yang Melakukan IPO, Jurnal Ekonomi Universitas Muhammadiyah Malang, volume 12 No 18, Januari-Juni 2002,pp. 297-314

Kim. Jeong Bong, I. Krinsky dan J. Lee, 1993, Motives for Going Public and Underpricing: New Finding from Korea, Journal of Business Finance and Accounting, 20 (2) January, pp. 195211

Krinsky. Itzhak dan Sherman. Cheung, 1994, Informations Asymmetry and Underpricing of Initial Public Offering, Further Empirical Evidence, Journal of Business and Accounting, 21(5), pp. 740-746

Leland dan D. Pyle, 1977, Information Asymmetries, Financial Structure and Financial Intermediation, The Journal of Finance 32. May: 371-387

Machfoed. Mahmud, Juli 1998, Faktor-faktor yang Mempengaruhi Praktik Perataan Laba pada Perusahaan yang Terdaftar di Bursa Efek Indonesia, Jurnal Riset Akuntansi Indonesia, Vol. 1, No. 2, Hal. 174-191 
McGuiness. Paul, 1992, An Examination of The Pricing of Initial Public Offering in Hongkong 1980-1990, Journal of Business Finance and Accounting, 19(2), January: 1165-186

Neill. J.D, Pourciau.S.G dan Schaefer.T.F, 1995, Accounting Method Choice and IPO Valuation, Accounting Horizons, 9(3), pp. 68-80

Naim. A dan Hartono, 1996, The Effect of Untitrust Investigations on Management of Earning: A Test on Political Cost Hyothesis. Kelola: Gadjah Mada University Business Review No.13/V, pp. 126-141s

Rao. Gita R, 1993, The Relation Between Stock Return and Earning: A Study of Newly-Public Firm. Working Paper. Kidder Peabody and Co. New York. Dalam Teoh, Siew Hong, Ivo Welch dan T.J Wong, 1998a, Earning Management and The Long Run Market Performance of Initial Public Offering. Journal of Finance, Vol. LIII. No. 6 Desember, pp. 1935-1974

Rajan. Raghuram dan Henry Servaes, 1997, Analysis Following and Initial Public Offering, The Journal of Finance, No. 52 June, pp. 507-529

Ritter. Jay R, 1991, The Long Run Performance of Initial Public Offering, Journal Finance Vol.46, pp.3-27

Rock. K, 1986, Why New Issues Are Underpriced, Journal of Financial Economics, 15 (January/February), pp. 187-212

Scott. William R, 1997, Financial Accounting Theory, Prentice-Hall International, Inc

Setiawati, Lilis, 1999, Penilaian Kesehatan Bank oleh Indonesia dan Manajemen Laba dalam Perbankan, Thesis S2 UGM, tidak dipublikasikan

Sweeney. A.P, 1994, Debt-Covenant Violations and Managers Accounting Response, Journal of Accounting ang Economics (May): pp 281-308

Sunariyah (1997), Analisis Informasi Prospektus Yang Berpengaruh Terhadap Return Awal Penawaran Perdana Di BEJ, Thesis S2 UGM, tidak dipublikasikan

Sutanto. I Intan (2000), Indikasi Manajemen Laba Menjelang IPO Oleh PerusahaanPerusahaan Yang Terdaftar di Bursa Efek Indonesia, Thesis S2 UGM, tidak dipublikasikan

Teoh. Siew Hong, Ivo. Welch dan T.J. Wong, 1998a, Earning Management and The Long Run Market Performance Of Initial Public Offering, Journal of Finance, Vol. LIII No. 6. Desember, pp. 1935-1974

Titman dan Trueman, 1986, An Explanation for Accounting Income Smoothing, Journal of Accounting Research, Suplement, pp. 127-143 
Trisnawati, Rina (1998), Pengaruh Informasi Prospektus Terhadap Return Saham di Pasar Perdana, Thesis S2 UGM, tidak dipublikasikan

Uang dan Effek No 43 Desember 1997

Usman. Umedi (2000), Analisis Rasio Untuk Mengukur Kinerja Perusahaan, Thesis S2 UNIBRAW,tidak dipublikasikan 